\title{
Pengaruh Harga, Lokasi, Kualitas Bangunan dan Promosi Terhadap Minat Beli Perumahan Taman Safira Bondowoso
}

\section{Elina Monica*}

Fakultas Ekonomi Universitas Muhammadiyah Jember

\section{A R T I C L E I N F O}

Article history:

Received 19 May 2018

Received in revised form

10 June 2018

Accepted 15 July 2018

Available online 27 August 2018

\section{Kata Kunci:}

harga, lokasi, kualitas

bangunan, promosi, minat

beli

Keywords:

price, place, building quality, promotion, buying interest

\begin{abstract}
A B S T R A K
Penelitian ini bertujuan untuk mengetahui pengaruh harga, lokasi, kualitas bangunan dan promosi secara parsial terhadap minat beli pada perumahan Taman Safira. Populasi dalam penelitian ini adalah seluruh pelanggan atau pengguna perumahan Taman Safira. Ukuran sampel ditentukan dengan rumus Slovin, dan diperoleh sampel sebanyak 67 responden. Pengujian hipotesis dilakukan dengan menggunakan analisis regresi linear berganda. Hasil yang didapat pada penelitian ini menunjukkan bahwa harga, lokasi, kualitas bangunan dan promosi berpengaruh positif dan signifikan terhadap minat beli. Hasil analisis koefisien determinasi menunjukan bahwa $77,9 \%$ minat beli dipengaruhi oleh harga, lokasi, kualitas bangunan dan promosi. Sedangkan sisanya sebesar $22,1 \%$ dipengaruhi oleh variabel lain diluar model.
\end{abstract}

A B S T R A C T

This study aims to determine the effect of price, place, building quality and promotion of partially to buying interest at Taman Safira Housing. The population in this study were all consumer or user Taman Safira Housing. Size of sampling definited with Slovin formula, and obtained a sample of 67 respondent. Hypothesis test in this research uses double degree linear regression. The result of this research show that price, place, building quality and promotion positive significantly influence on consumer decision. The results of coefficient determination shows that $77,9 \%$ of buying interest influenced by price, place, building quality and promotion. While the remaining $22,1 \%$ is influenced by other variables outside the model.

\footnotetext{
* Corresponding author.

E-mail addresses: Elinamonica18@gmail.com (Elina Monica)
} 


\section{Pendahuluan}

Kebutuhan manusia yang paling mendasar adalah tempat tinggal atau rumah. Setiap manusia membutuhkan tempat tinggal sebagai tempat untuk berlindung dan berkumpul dengan keluarga, disamping itu rumah juga digunakan sebagai investasi masa depan. Rumah merupakan kebutuhan dasar manusia dan mempunyai peran penting dalam penbentukan watak serta kepribadian seseorang (Mulyani, 2013).

Bisnis perumahan terus berkembang pesat sejalan dengan pertumbuhan penduduk. Bisnis perumahan atau biasa disebut property, saat ini menjadi lahan bisnis yang cukup diminati oleh para pengembang (Marisa, 2013). Hal ini ditandai dengan semakin banyaknya perusahaan yang menyediakan perumahan sebagai hunian penduduk. Semakin banyak bisnis perumahan maka semakin tinggi pula tingkat persaingan para developer dalam memasarkan produknya kepada konsumen. Para pelaku bisnis harus saling berlomba-lomba menyediakan dan memasarkan produknya dalam rangka memenuhi keinginan dan kebutuhan konsumen. Selain itu, perusahaan juga dituntut untuk berfikir cerdas dalam mengambil keputusan termasuk dalam hal perumusan strategi pemasaran yang tepat agar mampu menarik konsumen sehingga dapat terus bertahan (Ali, 2017).

Strategi pemasaran adalah serangkaian tujuan dan sasaran, kebijakan dan aturan yang memberi arah kepada usaha-usaha pemasaran perusahaan dari waktu ke waktu, pada masing-masing tingkatan dan acuan serta alokasinya, terutama sebagai tanggapan dari keadaan persaingan perusahaan yang selalu berubah (Assauri, 2008:15). Strategi juga merupakan serangakaian rancangan besar yang menggambarkan bagaimana sebuah perusahaan harus beroperasi untuk mencapai tujuan (Antyadika, 2012). Strategi pemasaran sangat penting bagi perusahaan agar dapat terus bertahan ditengah persaingan, dengan strategi pemasaran yang baik peruasahaan akan mampu menarik minat konsumen menggunakan dan memutuskan untuk membeli produk yang ditawarkan.

Minat beli adalah tahap dimana konsumen atau pembeli telah menentukan pilihannya dan melakukan pembelian produk serta mengkonsumsinya (Suharno dalam Ali, 2017). Pengambilan keputusan oleh konsumen untuk melakukan pembelian suatu produk diawali oleh adanya kesadaran atas kebutuhan dan keinginan (Ali, 2017). Selanjutnya jika sudah disadari adanya kebutuhan dan keinginan, maka konsumen akan mencari informasi mengenai keberadaan produk yang diinginkannya. Dari berbagai informasi yang diperoleh konsumen melakukan seleksi atas alternatif-alternatif yang tersedia. Seleksi ini dilakukan karena untuk beberapa kebutuhan konsumen akan sangat selektif dalam mempertimbangkan keputusan pembelian, salah satunya adalah rumah. Saidani , Basrah (2012) menyatakan bahwa Minat beli adalah tahap kecenderungan responden untuk bertindak sebelum keputusan membeli benar-benar dilaksanakan. Terdapat perbedaan antara pembelian aktual dan minat pembelian ulang. Resti (2010) dalam kajiannya menyatakan bahwa minat beli merupakan suatu proses perencanaan pembelian suatu produk yang akan dilakukan oleh konsumen dengan mempertimbangakan beberapa hal, diantaranya adalah banyak unit produk yang dibutuhkan dalam periode waktu tertentu, merek, dan sikap konsumen dalam mengkonsumsi produk tersebut.

Konsumen memutuskan pembelian rumah dengan mempertimbangkan faktor harga. Harga adalah sejumlah uang yang dibebankan atas suatu produk atau jasa atau jumlah dari nilai yang ditukar konsumen atas manfaat-manfaat karena memiliki atau menggunakan produk tersebut (Kotler \& Armstrong, 2006:439). Dalam proses penetapan harga suatu produk didasarkan atas pertimbangan besarnya biaya produksi dan berbagai faktor lainnya agar perusahaan dapat memperoleh laba. Selain itu, penetapan harga juga harus disesuaikan dengan keinginan, kebutuhan dan kemampuan konsumen agar perusahaan dapat menarik minat konsumen untuk membeli produk yang ditawarkan.

Faktor yang juga menjadi pertimbangan konsumen dalam membeli rumah adalah lokasi. Lokasi adalah tempat di mana perusahaan harus bermarkas melakukan operasi (Memah dkk, 2015). Pemilihan lokasi mempunyai fungsi yang strategis karena dapat ikut menentukan tercapainya tujuan badan usaha. Lokasi yang baik adalah lokasi yang terletak pada daerah yang strategis sehingga dapat memaksimumkan laba. Lokasi yang strategis dan akses ke lokasi yang terjangkau akan mengundang konsumen melakukan pembelian terhadap tempat tinggal.

Selain faktor harga dan lokasi, kualitas bangunan dapat menjadi faktor yang turut dipertimbangkan konsumen. Bangunan adalah wujud fisik hasil pekerjaan konstruksi yang menyatu dengan tempat kedudukan baik yang ada di bawah dan di atas tanah atau air (Sobirin dalam Prihandoyo dkk, 2015). Sedangkan kualitas bangunan merupakan ciri dan karakteristik suatu bangunan atau hasil konstruksi yang berpengaruh pada kemampuannya memenuhi harapan dan kebutuhan konsumen. Kualitas bangunan dapat dinilai dari tingkat keandalannya, keawetan, kemudahan perawatan dan kenyamanan (Sutianingsih, 2010). Bangunan yang berkualitas tentu saja memiliki nilai tambah di mata konsumen, sehingga dapat mempengaruhi keputusan konsumen untuk membeli rumah tersebut. Terciptanya suatu 
lingkungan permukiman dipengaruhi oleh factor sosial ekonomi penduduk yang menempatinya. Indikator - indikator yang berpengaruh terhadap kualitas permukiman antara lain: jenis pekerjaan, pendapatan, pendidikan, jumlah anggota keluarga, luas lahan dan sebagainya (Mbina Pinem, 2010). Nurdasila (2008) menyatakan bahwa faktor kualitas bangunan, disain dan harga merupakan faktor pertimbangan utama dalam penilaian kepuasan penghuni

Faktor promosi juga berperan penting dalam pemasaran. Tanpa adanya promosi, konsumen tidak akan pernah tau bahwa produk yang ditawarkan ada. Menurut Tjiptono (2001:219) promosi adalah aktivitas pemasaran dengan cara menyebarkan informasi, mempengaruhi, membujuk dan mengingatkan pasar sasaran agar bersedia menerima, membeli, dan loyal pada produk. Perusahaan harus mengatur strategi promosi yang tepat agar produk perusahaan bisa dikenal oleh konsumen. Dengan promosi yang tepat dengan informasi yang terkandung dalam promosi tersebut, maka konsumen akan tertarik membeli suatu produk.

Berdasarkan penjelasan di atas penelitian ini mencoba mengetahui pengaruh harga, lokasi, kualitas bangunan dan promosi terhadap keputusan konsumen dalam pembelian perumahan. Alasan pemilihan variabel independen tersebut mengacu pada hasil penelitian terdahulu yang dilakukan oleh Santoso (2015), Rakhmanita dan Vidada (2017) dan Sutianingsih (2010) yang menemukan hasil bahwa kualitas produk atau bangunan, harga, lokasi, dan promosi berpengaruh positif dan signifikan terhadap keputusan pembelian perumahan. Pada penelitian lainnya, Ali (2017) menemukan hasil bahwa kualitas produk atau bangunan, harga dan lokasi berpengaruh positif dan signifikan terhadap keputusan pembelian perumahan.

Penelitian ini menggunakan perumahan Taman Safira sebagai objek penelitian. Taman Safira adalah perumahan yang didirikan oleh PT. Gemilang Citra Persada sebagai salah satu pengembang perumahan yang menyediakan rumah dengan berbagai tipe. Taman Safira terletak dijalan Situbondo, traktakan Wonosari, Bondowoso. Perumahan Taman Safira mulai berdiri sejak tahun 2014. Perumahan ini memiliki keunggulan yaitu harga yang terjangkau, desain bangunan yang menarik, lokasi perumahan yang strategis, dan fasilitas-fasilitas yang lengkap.

Sistem Tata Kota yang diberlakukan di Bondowoso serta perkembangan jumlah penduduk dan tingkat perekonomian yang ada semakin mendorong para perusahaan pengembang untuk melakukan pembangunan property di berbagai daerah. Para pengembang Perumahan tidak hanya dituntut untuk memproduksi saja, akan tetapi perlu berusaha menarik konsumen dan mempengaruhi tingkah laku konsumen untuk membeli produk yang ditawarkan. Pemahaman terhadap perilaku dan sikap konsumen sangat mempengaruhi penjualan produk baik untuk saat ini maupun untuk memperkirakan penjualan dimasa yang akan datang. Data mengenai jumlah penjualan perumahan Taman Safira dapat dilihat pada Tabel 1 di bawah ini:

Tabel 1. Penjualan Perumahan "Taman Safira"

\begin{tabular}{llll}
\hline Tahun & Target Penjualan & Realisasi Penjualan & Pencapaian (\%) \\
\hline 2014 & 150 & 124 & 62 \\
2015 & 200 & 168 & 84 \\
2016 & 200 & 186 & 93 \\
2017 & 200 & 200 & 100 \\
\hline
\end{tabular}

Sumber : Data Taman Safira Tahun 2017

Dari Tabel 1 di atas dapat diketahui bahwa pada tahun 2014 target penjualan yang harus dicapai adalah 150 unit, sedangkan realisasi penjualan yang berhasil dicapai adalah sebesar 124 unit atau 62\% dari jumlah total perumahan yang tersedia. Pada tahun 2015 perusahaan pengembang mampu menambah penjualan sebanyak 44 unit, sehingga perumahan yang terjual sebanyak 168 unit atau $84 \%$ dari total perumahan yang tersedia. Pada tahun 2016 jumlah perumahan yang terjual sebanyak 18 unit, sehingga jumlah yang terjual sudah mencapai $93 \%$ atau 186 unit. Selanjutnya pada tahun 2017 perusahaan pengembang telah mampu menjual seluruh unit perumahan Taman Safira yaitu sebanyak 200 unit perumahan.

Dari data di atas dapat disimpulkan bahwa pencapaian realisasi penjualan perumahan Taman Safira selama empat tahun terakhir belum mencapai target yang diinginkan. Tidak tercapainya target penjualan Taman Safira dikarenakan pada kurun waktu tersebut pihak pengembang lebih memfokuskan pada penyelesaian pembangunan perumahan Taman Mutiara dan Lumbung Asri. Walaupun demikian, Taman Safira sudah dapat dikatakan optimal dalam pemasaran produknya. Hal ini dibuktikan dengan tercapainya penjualan seluruh unit perumahan Taman Safira selama kurun waktu empat tahun. Tercapainya penjualan tersebut, dapat dijadikan indikasi bahwa konsumen percaya dan merasa tepat memilih dan 
memutuskan perumahan Taman Safira sebagai tempat tinggal. Hal ini perlu diperhatikan oleh perusahaan pengembang lainnya dalam menciptakan dan memasarkan produk, sehingga produk perumahan yang ditawarkan mampu terjual dengan baik. Oleh karena itu dibutuhkan penelitian lebih lanjut lagi untuk mengetahui faktor-faktor apa saja yang menjadi pertimbangan masyarakat atau konsumen dalam menetapkan keputusan pembelian perumahan di Taman Safira Bondowoso.

Tujuan dari penelitian ini adalah untuk menguji dan menganalisa pengaruh harga, lokasi, kualitas bangunan dan promosi terhadap minat beli perumahan Taman Safira.

\section{Metode}

Desain penelitian ini adalah penelitian kausalitas. Penelitian kausalitas bertujuan mengukur kekuatan hubungan antara dua variabel atau lebih, juga menunjukkan arah hubungan antara variabel bebas dan terikat. Secara umum tujuan penelitian ini untuk melihat, membuktikan dan menganalisis apakah harga, lokasi, kualitas bangunan dan promosi berpengaruh terhadap minat beli.

Populasi dalam penelitian ini adalah seluruh pembeli perumahan Taman Safira di Bondowoso, yaitu sebanyak 200 unit. Sedangkan untuk menghitung penentuan jumlah sampel dari populasi tertentu, penelitian ini menggunakan rumus Slovin dan diperoleh angka 67 responden.

\section{Hasil dan pembahasan}

\section{Uji Instrumen Data}

1. Uji Validitas

Uji validitas dilakukan dengan tujuan untuk mengetahui kehandalan kuesioner. Item pernyataan dianggap valid apabila bilai $r$ hitung lebih besar dibandingkan $r$ tabel. Berikut hasil uji validitas dalam penelitian ini:

Tabel 2. Hasil Uji Validitas

\begin{tabular}{lllll}
\hline No & Variabel & r hitung & r tabel & Ket \\
\hline 1 & Harga 1 & 0,665 & 0,2404 & Valid \\
& Harga 2 & 0,824 & & Valid \\
& Harga 3 & 0,873 & Valid \\
& Harga 4 & 0,721 & Valid \\
& Lokasi 1 & 0,689 & 0,2404 & Valid \\
& Lokasi 2 & 0,787 & & Valid \\
& Lokasi 3 & 0,752 & & Valid \\
& Lokasi 4 & 0,816 & & Valid \\
& Lokasi 5 & 0,594 & & Valid \\
3 & K. Bangunan 1 & 0,737 & 0,2404 & Valid \\
& K. Bangunan 2 & 0,744 & & Valid \\
& K. Bangunan 3 & 0,694 & & Valid \\
& K. Bangunan 4 & 0,653 & & Valid \\
& K. Bangunan 5 & 0,640 & & Valid \\
4 & Promosi 1 & 0,695 & & Valid \\
& Promosi 2 & 0,766 & & Valid \\
& Promosi 3 & 0,625 & & Valid \\
& Promosi 4 & 0,688 & & Valid \\
& Promosi 5 & 0,718 & & Valid \\
5 & Kep.Konsumen 1 & 0,773 & & Valid \\
& Kep.Konsumen 2 & 0,656 & Valid \\
& Kep.Konsumen 3 & 0,520 & Valid \\
& Kep.Konsumen 4 & 0,672 & Valid \\
& Kep.Konsumen 5 & 0,745 & & Valid \\
\hline
\end{tabular}

Dari data di atas diketahui bahwa semua item pernyataan dalam kuesioner memiliki nilai $r$ hitung lebih besar dari $r$ tabel yaitu sebesar 0,2404 artinya semua item yang digunakan dalam penelitian ini dapat dikatakan valid. 


\section{Uji Reliabilitas}

Uji reliabilias kuesioner dilakukan dengan tujuan untuk mengetahui konsistensi dan stabilitas dari alat ukur. Hasil uji reliabilitas penelitian disajikan pada tabel di bawah ini:

Tabel 3. Hasil Uji Reliabilitas

\begin{tabular}{llll}
\hline No. & Variabel & Cronbach Alpha & Ket \\
1. & Harga & 0,765 & Reliabel \\
\hline 2. & Lokasi & 0,778 & Reliabel \\
3. & Kualitas Bangunan & 0,731 & Reliabel \\
4. & Promosi & 0,738 & Reliabel \\
5. & Keputusan Konsumen & 0,705 & Reliabel \\
\hline
\end{tabular}

Dari nilai di atas diketahui masing-masing item memiliki nilai yang lebih besar dari 0,7 artinya semua item yang digunakan dalam penelitian ini adalah reliabel.

\section{Analisis Data}

1. Uji Asumsi Klasik

a. Uji Normalitas

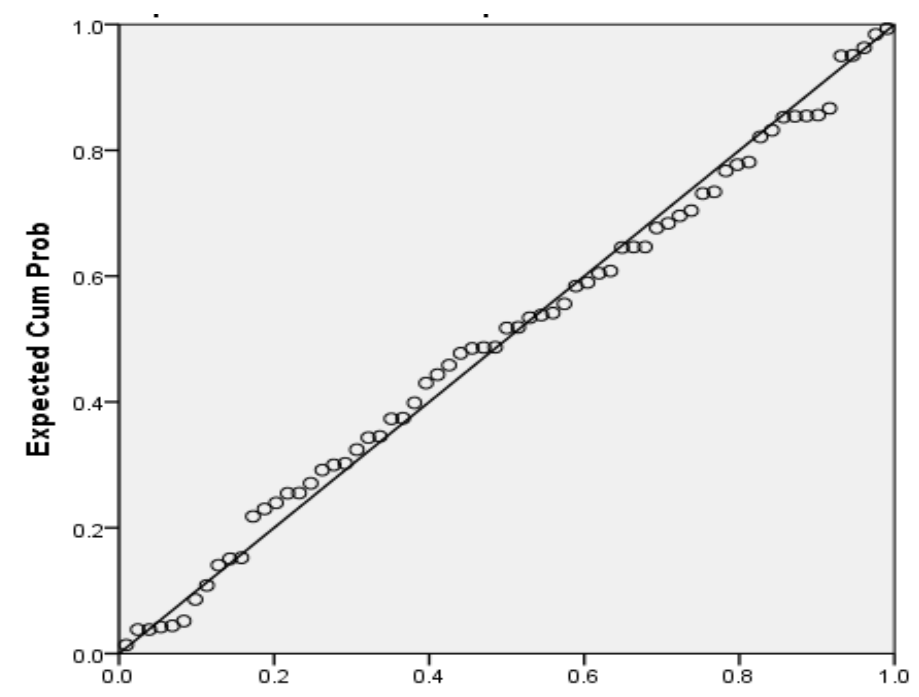

Gambar 1 Hasil Uji Normalitas

Hasil menunjukkan data menyebar di sekitar garis diagonal dan mengikuti arah garis diagonal, maka model regresi memenuhi asumsi normalitas.

b. Uji Multikolinearitas

Tabel 4. Hasil Uji Multikolinearitas

\begin{tabular}{llll}
\hline No. & Variabel & Tolerance & VIF \\
\hline 1. & Harga & 0,994 & 1,006 \\
2. & Lokasi & 0,296 & 3,374 \\
3. & Kualitas Bangunan & 0,235 & 4,250 \\
& & 0,264 & 3,791 \\
\hline
\end{tabular}

Hasil menunjukkan masing-masing variabel memiliki nilai VIF kurang dari 10, sehingga dapat disimpulkan tidak terjadi multikolinearitas. 
c. Uji Heteroskedastisitas

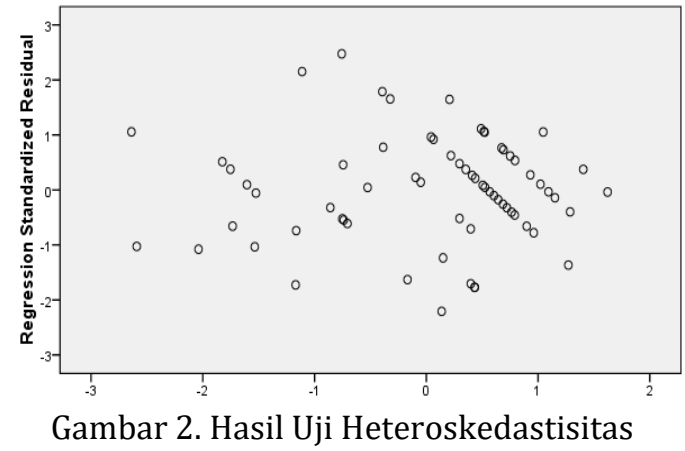

Dari gambar 2 di atas, dapat dilihat bahwa pola tidak terlihat jelas dan titik-titik menyebar di atas dan di bawah adalah angka nol pada sumbu, sehingga variabel penelitian dapat disimpulkan tidak ada heteroskedastisitas.

2. Regresi Linier Berganda

Analisis linier berganda digunakan untuk memperoleh gambaran menyeluruh mengenai hubungan antara variabel satu dengan variabel lainnya. Adapun hasil analisis linier berganda disajikan pada tabel di bawah ini:

Tabel 5. Hasil Uji Regresi Linier Berganda

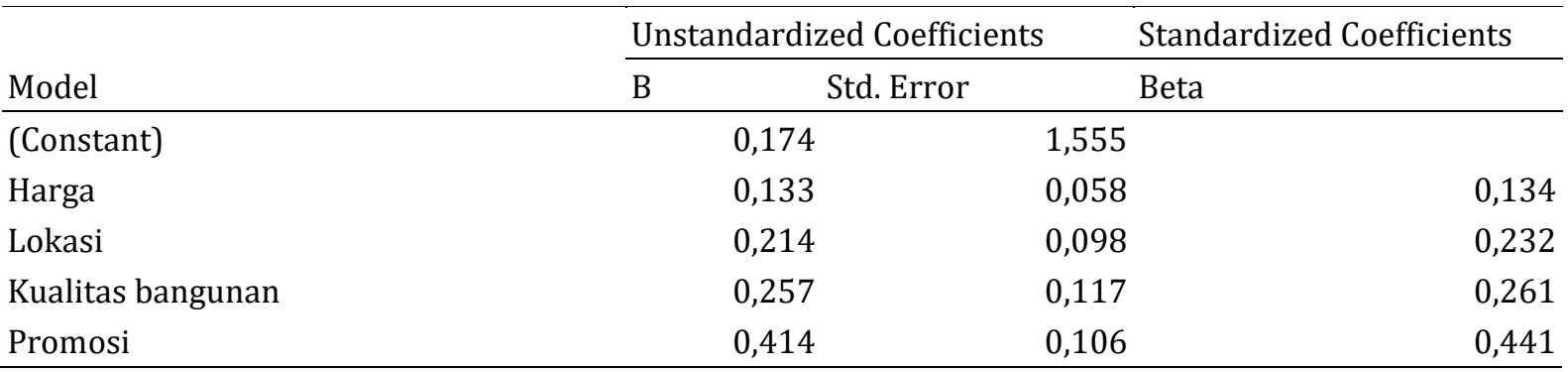

Hasil dari perhitungan analisis regresi linier berganda diperoleh persamaan:

Keputusan Pembelian = 0,174 + 0,133X1 + 0,214X2 + 0,257X3 + 0,414X4

Dari persamaan regresi dapat dilihat nilai konstanta sebesar 0,174 , yang artinya bahwa jika variabel independen yang meliputi kualitas pelayanan, ketersediaan fasilitas, dan kemudahan birokrasi dianggap konstan maka besarnya nilai adalah sebesar 0,174. Koefisien regresi variabel harga bernilai positif sebesar 0,133, yang berarti bahwa peningkatan harga sebesar satu satuan akan terjadi peningkatan keputusan konsumen sebesar 0,133 dengan asumsi variabel bebas lainnya konstan. Begitupula dengan nilai variabel lokasi, kualitas bangunan dan promosi yang bernilai positif sebesar 0,$214 ; 0,257$; dan 0,414 pada masing-masing variabel.

\section{Uji Hipotesis}

1. Uji t

Untuk mengetahui pengaruh variabel independen terhadap variabel dependen secara parsial, penelitian ini menggunakan uji t dengan tingkat signifikansi 5\%.

Tabel 6. Hasil Uji t

\begin{tabular}{lllll}
\hline No. & Variabel & t-hitung & t-tabel & Sig. \\
\hline 1. & Harga & 2,306 & 1,67155 & 0,024 \\
2. & Lokasi & 2,179 & & 0,033 \\
3. & Kualitas Bangunan & 2,191 & 0,032 \\
4. & Promosi & 3,191 & 0,000 \\
\hline
\end{tabular}

Nilai t-hitung variabel harga adalah sebesar 2,306 dengan tingkat signifikansi sebesar 0,024, sedangkan nilai t-tabel adalah sebesar 1,67155, sehingga t-hitung > t-tabel $(2,306>1,67155)$. Hal ini 
menunjukkan bahwa variabel harga secara parsial mempunyai pengaruh positif dan signifikan terhadap keputusan konsumen.

Nilai t-hitung variabel lokasi adalah sebesar 2,179 dengan tingkat signifikansi sebesar 0,033, sedangkan nilai $t$-tabel adalah sebesar 1,67155, sehingga t-hitung $>$ t-tabel $(2,179>1,67155)$. Hal ini menunjukkan bahwa variabel lokasi secara parsial mempunyai pengaruh positif dan signifikan terhadap keputusan konsumen.

Nilai t-hitung variabel kualitas bangunan adalah sebesar 2,191 dengan tingkat signifikansi sebesar 0,032 , sedangkan nilai t-tabel adalah sebesar 1,67155, sehingga t-hitung $>t$-tabel $(2,191>1,67155)$. Hal ini menunjukkan bahwa variabel kualitas bangunan secara parsial mempunyai pengaruh positif dan signifikan terhadap keputusan konsumen.

Nilai t-hitung variabel promosi adalah sebesar 3,191 dengan tingkat signifikansi sebesar 0,000, sedangkan nilai $t$-tabel adalah sebesar 1,67155, sehingga t-hitung $>$ t-tabel $(3,191>1,67155)$. Hal ini menunjukkan bahwa variabel harga secara parsial mempunyai pengaruh positif dan signifikan terhadap keputusan konsumen.

2. Koefisien determinasi

Koefisien Determinasi $\left(\mathrm{R}^{2}\right)$ digunakan untuk mengetahui seberapa besar kemampuan variabel independen dapat menerangkan variabel dependennya. Hasil perhitungan $\mathrm{R}^{2}$ dalam penelitian ini dapat dilihat dalam tabel di bawah ini:

Tabel 7. Hasil Uji Koefisien Determinasi

\begin{tabular}{llll}
\hline Model & $\mathrm{R}$ & R Square & Adjusted R Square \\
\hline 1. & $0,890^{\mathrm{a}}$ & 0,792 & 0,779 \\
\hline
\end{tabular}

Berdasarkan data di atas, diketahui bahwa nilai $\mathrm{R}^{2}$ sebesar 0,779 , yang artinya bahwa harga, lokasi, kualitas bangunan dan promosi berpengaruh $77,9 \%$ terhadap keputusan konsumen, sedangkan sisanya sebesar $22,1 \%$ dipengaruhi oleh faktor lain di luar model.

\section{Pembahasan}

Pembahasan masing-masing variabel dapat dilihat sebagai berikut:

1. Pengaruh Harga terhadap Keputusan Konsumen

Harga merupakan sejumlah uang yang dibutuhkan untuk memperoleh suatu produk yang diinginkan. Dalam menetapkan harga dari suatu produk atau jasa, perusahaan seharusnya memperhatikan kesesuaian antara nilai manfaat dan kualitas produk serta harga yang ditawarkan pesaing untuk produk yang sama. Perusahaan yang menetapkan harga sesuai dengan penilaian dan keinginan konsumen, maka dapat dikatakan perusahaan tersebut mampu menciptakan nilai yang tinggi dari sebuah harga. Dengan demikian setiap kenaikan nilai harga, maka keputusan konsumen untuk membeli produk dalam hal ini perumahan juga akan semakin meningkat.

Hal tersebut sesuai dengan hasil pengujian yang membuktikan bahwa variabel harga secara parsial berpengaruh positif dan signifikan terhadap keputusan konsumen perumahan Taman Safira. Hasil temuan ini sejalan dengan hasil penelitian yang dilakukan Santoso (2015), Rakhmanita dkk (2017), Ali (2017), Sutianingsih (2010) dan Visitnitikija dan Chonphunnon (2016) yang menemukan hasil bahwa harga berpengaruh signifikan terhadap keputusan konsumen dalam pembelian perumahan.

2. Pengaruh Lokasi terhadap Keputusan Konsumen

Lokasi adalah tempat perusahaan beroperasi atau tempat perusahaan melakukan kegiatan untuk menghasilkan barang dan jasa yang mementingkan segi ekonominya (Tjiptono, 2001:92). Dalam memilih tempat tinggal, lokasi merupakan salah satu faktor yang dipertimbangkan konsumen. Lokasi yang strategis dan akses yang mudah akan mengundang konsumen melakukan pembelian terhadap suatu produk dalam hal ini perumahan (Memah, 2015). Oleh karena itu, semakin baik dan strategis lokasi yang dipilih perusahaan maka keputusan konsumen untuk membeli perumahan juga semakin meningkat.

Hal tersebut sesuai dengan hasil pengujian yang membuktikan bahwa variabel harga secara parsial berpengaruh positif dan signifikan terhadap keputusan konsumen perumahan Taman Safira. Hasil temuan ini sejalan dengan hasil penelitian yang dilakukan Rakhmanita dkk (2017), Ali (2017), Sutianingsih (2010) dan Visitnitikija dan Chonphunnon (2016) yang menemukan hasil bahwa lokasi berpengaruh positif dan signifikan terhadap keputusan konsumen dalam pembelian perumahan,

3. Pengaruh Kualitas Bangunan terhadap Keputusan Konsumen

Kualitas bangunan merupakan ciri dan karakteristik suatu bangunan atau hasil konstruksi yang berpengaruh pada kemampuannya memenuhi harapan dan kebutuhan konsumen. Kualitas bangunan 
adalah faktor yang paling dipertimbangkan oleh konsumen dalam membeli hunian atau rumah. Bangunan rumah yang berkualitas akan memberikan ketahanan dan kenyamanan bagi konsumen atau penghuni. Oleh karena itu, semakin baik dan berkualitasnya bangunan yang diciptakan perusahaan, maka keputusan konsumen untuk membeli perumahan juga semakin meningkat.

Hal tersebut sesuai dengan hasil pengujian yang membuktikan bahwa variablel kualitas bangunan secara parsial berpengaruh positif dan signifikan terhadap keputusan konsumen perumahan Taman Safira. Hasil temuan ini sejalan dengan hasil penelitian yang dilakukan Rakhmanita dkk (2017), Ali (2017), Sutianingsih (2010) dan Visitnitikija dan Chonphunnon (2016) yang menemukan hasil bahwa kualitas bangunan berpengaruh positif dan signifikan terhadap keputusan konsumen membeli perumahan.

4. Pengaruh Promosi terhadap Keputusan Konsumen

Promosi adalah aktivitas yang berusaha menyebarkan informasi, untuk mempengaruhi, membujuk dan mengingatkan pasar sasaran agar bersedia menerima, membeli, dan loyal pada produk yang ditawarkan perusahaan (Tjiptono, 2001:219). Tanpa adanya promosi, konsumen tidak akan mengetahui keberadaan dari suatu produk dan konsumen tidak akan pernah membelinya. Oleh karena itu, semakin baik dan luasnya kegiatan promosi yang dilakukan perusahaan untuk memperkenalkan suatu perumahan, maka keputusan konsumen untuk membeli perumahan tersebut juga semakin meningkat.

Hal tersebut sesuai dengan hasil pengujian yang membuktikan bahwa variabel promosi secara parsial berpengaruh positif dan signifikan terhadap keputusan konsumen perumahan Taman Safira. Hasil temuan ini sejalan dengan hasil penelitian yang dilakukan Santoso (2015), Rakhmanita dkk (2017), Sutianingsih (2010) dan Visitnitikija dan Chonphunnon (2016) yang menemukan hasil bahwa promosi berpengaruh positif dan signifikan terhadap keputusan konsumen dalam pembelian perumahan

\section{Simpulan dan saran}

Berdasarkan analisis data dan pembahasan yang telah dikemukakan, maka hasil penelitian ini dapat disimpulkan sebagai berikut: 1 . Harga berpengaruh positif dan signifikan terhadap keputusan konsumen perumahan Taman Safira, 2. Lokasi berpengaruh positif dan signifikan terhadap keputusan konsumen perumahan Taman Safira, 3. Kualitas Bangunan berpengaruh positif dan signifikan terhadap keputusan konsumen perumahan Taman Safira, 4. Promosi berpengaruh positif dan signifikan terhadap keputusan konsumen perumahan Taman Safira

Saran yang dapat penulis ajukan sehubungan dengan hasil penelitian ini yaitu: 1. Untuk perusahaan: hasil penelitian menunjukkan bahwa harga, lokasi, kualitas bangunan dan promosi berpengaruh signifikan terhadap keputusan konsumen, sehingga untuk proyek selanjutnya perusahaan diharapkan mampu mempertahankan dan meningkatkan nilai harga, lokasi, kualitas bangunan dan promosi sehingga konsumen tertarik untuk melakukan pembelian, dan 2. Untuk peneliti berikutnya diharapkan dapat menggunakan objek yang lebih luas dengan memilih seluruh perumahan di Bondowoso, agar diperoleh hasil yang dapat digeneralisasikan..

\section{Daftar Rujukan}

Ali, Muhammad Taufik Rachman. 2017. Pengaruh Harga, Kualitas Produk, Lokasi, Dan Fasilitas Terhadap Keputusan Pembelian Rumah. Jurnal Ilmu dan Riset Manajemen Vol.6 No.9. STIESIA: Surabaya

Antyadika, Bonaventura Efrian. 2012. Analisis Pengaruh Lokasi, Harga Dan Kualitas Produk Terhadap Keputusan Pembelian. Skripsi. Universitas Diponegoro: Semarang

Assauri, Sofyan. 2008. Manajemen Pemasaran, Dasar Konsep Dan Strategi. Raja Grafindo: Jakarta

Kotler, Philip Dan Armstong, Gary. 2006. Marketing Management. Prentice Hall: Newjersey

Marisa, Nisa. 2013. Analisis Faktor-Faktor Yang Mempengaruhi Keputusan Pembelian Terhadap Kawasan Perumahan Mustika Plamongan Elok Semarang. Jurnal Sains Pemasaran Indonesia Vol.XII No.3. Semarang

Mbina Pinem .2010."Pengaruh Sosial Ekonomi Terhadap Kualitas Permukiman Di Kelurahan Sidorejo Kecamatan Medan Tembung Kota Medan". Dosen Jurusan Pendidikan Geografi Universitas Negeri Medan. Jurnal Geografi Vo.l 2 No. 2 Agustus 2010. 
Memah, Deisita, dkk. 2015. Analisis Strategi Promosi, Harga, Lokasi, Dan Fasilitas Terhadap Keputusan Pembelian Rumah Di Citraland Manado. Jurnal EMBA. Universitas Sam Ratulangi: Manado

Mulyani, Tri. 2013. Studi Exploratif Tingkat Kepuasan Penghuni Terhadap Kondisi Bangunan Perumahan Ayodya Bersemi 2 Kota Purwodadi Kabupaten Grobogan Proinsi Jawa Tengah. Skripsi. Universitas Negeri Semarang: Semarang

Nurdasila Darsono and Mukhlis Yunus, (2008), Pengaruh Kualitas Bangunan dan Kualitas Pelayanan terhadap Kepuasan Penerima Rumah Bantuan: Studi komparatif bantuan ADB dan non-ADB di Banda Aceh.

Prihandoyo, C dkk. 2015. Analisis Pengaruh Harga, Lokasi, Bangunan Dan Lingkungan Terhadap Keputusan Konsumen Membeli Rumah. Jurnal. Universitas Balikpapan: Balikpapan

Rakhmanita, Ani dan Vidada, Irwin Ananta. 2017. Faktor-Faktor Yang Mempengaruhi Keputusan Pembelian Properti Di Kota Tangerang. Jurnal Seminar Nasional Multi Disiplin Ilmu Vol.1. BSI: Jakarta

Resti Meldarianda.2010."Pengaruh Store Atmosphere Terhadap Minat Beli Konsumen Pada Resort Café Atmosphere Bandung". Jurnal Bisnis dan Ekonomi (JBE), September 2010, Hal. 97 - 108 Vol. 17, No. $2(97)$.

Saidani , Basrah dan Samsul Arifin.2012."Pengaruh Kualitas Produk Dan Kualitas Layanan Terhadap Kepuasan Konsumen Dan Minat Beli Pada Ranch Market". Jurnal Riset Manajemen Sains Indonesia (JRMSI) |Vol. 3, No. 1, 2012 (1).

Santoso, B, 2015, Faktor factor yang mempengaruhi minat beli jasa biro perjalanan wisata 'HOBI \& TRAVEL JEMBER, Jurnal Ilmu manajemen dan Bisnis Vol 1 No,1 UM Jember

Sutianingsih. 2010. Keputusan Konsumen Dalam Membeli Perumahan. Jurnal Riset Manajemen Dan Akuntansi Vol.1 No.2. STIE Atma Bhakti: Surakarta

Tjiptono, Fandy. 2001. Strategi Pemasaran Edisi Pertama. Andi Offset:Yogyakarta

Visitnitikija, Chinnaso and Chonphunnon, Asmaporn. 2016. Factors Effecting Consumer Behavior of Buying a Single Housing Estate. IRJAES Vol.2 Issue.1. Kasembundit University: Bangkok 